\title{
Estimation of Biochemical Oxygen Demand Based on Dissolved Organic Carbon, UV Absorption, and Fluorescence Measurements
}

\author{
Jihyun Kwak, ${ }^{1}$ Bumju Khang, ${ }^{1}$ Eunhee Kim, ${ }^{1}$ and Hyunook Kim ${ }^{2}$ \\ ${ }^{1}$ Century Technology Company, Ansan 426-901, Republic of Korea \\ ${ }^{2}$ Department of Environmental Engineering, University of Seoul, Seoul 130-743, Republic of Korea \\ Correspondence should be addressed to Hyunook Kim; h_kim@uos.ac.kr
}

Received 10 September 2012; Revised 7 November 2012; Accepted 7 November 2012

Academic Editor: Mohammad A. Al-Ghouti

Copyright (C) 2013 Jihyun Kwak et al. This is an open access article distributed under the Creative Commons Attribution License, which permits unrestricted use, distribution, and reproduction in any medium, provided the original work is properly cited.

\begin{abstract}
Determination of 5- $\mathrm{d}$ biochemical oxygen demand $\left(\mathrm{BOD}_{5}\right)$ is the most commonly practiced test to assess the water quality of surface waters and the waste loading. However, $\mathrm{BOD}_{5}$ is not a good parameter for the control of water or wastewater treatment processes because of its long test period. It is very difficult to produce consistent and reliable $\mathrm{BOD}_{5}$ results without using careful laboratory quality control practices. This study was performed to develop software sensors to predict the $\mathrm{BOD}_{5}$ of river water and wastewater. The software sensors were based on the multiple regression analysis using the dissolved organic carbon (DOC) concentration, UV light absorbance at $254 \mathrm{~nm}$, and synchronous fluorescence spectra. River water samples and wastewater treatment plant (WWTP) effluents were collected at 1-hour interval to evaluate the feasibility of the software sensors. In short, the software sensors developed in this study could well predict the $\mathrm{BOD}_{5}$ of river water $(r=0.78)$ and for the WWTP effluent $(r=0.90)$.
\end{abstract}

\section{Introduction}

The determination of 5-d biochemical oxygen demand $\left(\mathrm{BOD}_{5}\right)$ is the standardized experimental procedure to determine the relative oxygen requirements for aqueous microbes to consume organic materials in wastewaters, wastewater treatment plant (WWTP) effluent, or natural waters [1]. $\mathrm{BOD}_{5}$ has been used as an indicator for the amount of organic pollutants in most aquatic systems, especially a good indicator for biodegradable organic compounds [2]. Due to the 5 - $\mathrm{d}$ test period, however, $\mathrm{BOD}_{5}$ is not considered as a suitable parameter for a process control of water treatment processes and for a real-time water quality monitoring system, in which a rapid feedback is essential [3]. The $\mathrm{BOD}_{5}$ based biodegradation test that relies upon the presence of a viable microbial community has a difficulty in consistently acquiring accurate measurements [4]. $\mathrm{BOD}_{5}$ generally has an uncertainty of $15 \% \sim 20 \%$.

In order to overcome the shortcoming of the conventional $\mathrm{BOD}_{5}$ test, biosensors, UV-visible spectrophotometry, fluorescence measurements, and software sensor (virtual sensors) have been suggested as an alternative method to determine the $\mathrm{BOD}_{5}$ of a water sample.
Most $\mathrm{BOD}_{5}$ biosensors rely on the measurement of the respiratory activity of cells by a suitable transducer. In addition, the ones using an oxygen electrode, a carbon dioxide analyzer, an optical transducer or a microbial fuel cell have recently been reported [5]. Biosensors allow the researchers to conveniently and rapidly (15 minute) obtain the $\mathrm{BOD}_{5}$ result, compared with the official $\mathrm{BOD}_{5}$ method [6].

Single or mixed cultures are used in biosensors. Since a single strain is not able to oxidize the entire range of organic contaminants in water samples, and the DO consumption is, thus, not always directly proportional to the concentration of biodegradable organics, mixed cultures like activated sludge have been preferred [7]. Even in the case of mixed cultures, however, the activity of the microbes is easily affected by the changes of environmental condition, such as concentrations of nutrients, temperature, and $\mathrm{pH}$ resulting in inaccurate $\mathrm{BOD}_{5}$ values [8].

Dissolved organic compounds with aromatic structures strongly absorb UV radiation [9]. Based on the principle, the UV-visible spectrophotometry of a water sample is hypothesized to have a linear relation with water total organic carbon (TOC), nitrate, suspended solids (SSs), chemical 
oxygen demand (COD), $\mathrm{BOD}_{5}$ or dissolved organic carbon (DOC) [10]. Alternatively, the UV light absorbance at $254 \mathrm{~nm}$ has been utilized to directly estimate the aggregate organic content of a water sample [11]. If this approach is to be applied for the $\mathrm{BOD}_{5}$ determination, target water samples should not contain other light-absorbing chemicals or materials like nitrate or SS [3].

Fluorescence measurements have been applied to determine the presence of humic substances and organic matters in natural waters. Among a few fluorescence analysis methods, synchronous fluorescence spectroscopy is the best way to scan the entire section of excitation wavelengths by fixing the excitation and emission wavelengths uniformly. This method allows obtaining a better resolution and producing various information regarding the DOMs in water [12]. Recently, the method has been successfully applied to identify microbial communities in water and to establish the correlation between water $\mathrm{BOD}_{5}$ and the microbial activity $[4,13]$. Since the $\mathrm{BOD}_{5}$ test is a microbial assessment of organic substance load, the "microbial" tryptophan-like fluorescence was found correlated with the activity of a microbial community and the absolute $\mathrm{BOD}_{5}$ values of water samples [4]. The optical parameters of tryptophanlike fluorescence use diverse specific excitation/emission wavelengths: for example, $248 \mathrm{~nm} / 340 \mathrm{~nm}, 280 \mathrm{~nm} / 350 \mathrm{~nm}$, $220-230 \mathrm{~nm} / 340-370 \mathrm{~nm}, 220 \mathrm{~nm} / 350 \mathrm{~nm}, 280 \mathrm{~nm} / 350 \mathrm{~nm}$, and so forth. However, the $\mathrm{BOD}_{5}$ determination based on the fluorescence peaks obtained from water samples is still infancy. In order to estimate the $\mathrm{BOD}_{5}$, however, more information should be obtained in addition to the tryptophan-like fluorescence, since real environmental water contains other oxidizable minerals and carbohydrates as well as biodegradable organic matter [14]. Even the water collected near the discharge of an industrial wastewater treatment plant (WWTP) may contain toxic substances such as heavy metals that can inhibit the oxidation of organic compounds by bacteria [15]. Moreover, the water fluorescence is often affected by water $\mathrm{pH}$, temperature, and SS. In fact, the approach has been applied only to wastewater samples, the $\mathrm{BOD}_{5}$ of which varies wide [2].

Recently, a few researchers have utilized both UV-visible spectrophotometry and fluorescence measurements together to estimate the $\mathrm{BOD}_{5}$ in waters. Applying the sensors to the environmental monitoring is advantageous since they are rapid and versatile. In addition, they require low operating costs, no chemicals, and no sample pretreatment for measurements. However, their application to water samples can be very limited if the SS concentration of the samples is high [16].

A software sensor (in other words, virtual sensors) generates virtual signals for the water quality parameter of interest through the calculation of a model fed with real signals from reliable, available sensors for other parameters [17]. It rapidly predicts the effect of changes in other water quality parameters on the target parameter. Since the software sensor does not obtain its result from physical measurements, however, the uncertainty associated with its result can be large [3]. Hence, it has been suggested that a software sensor

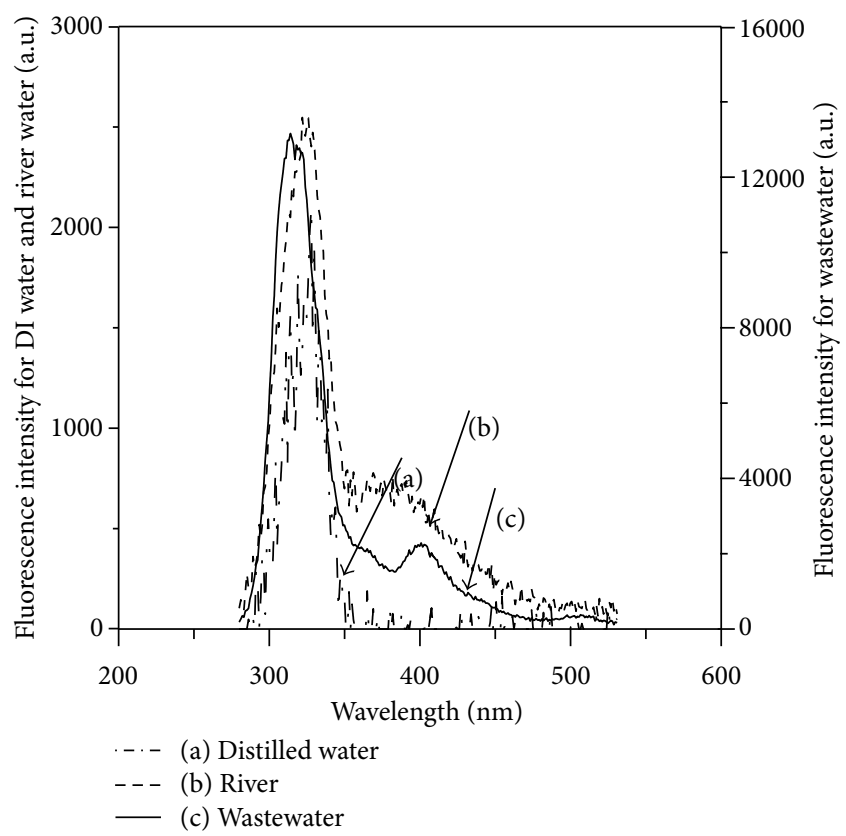

FIGURE 1: Synchronous fluorescence spectra of (a) DI water (b) river water, and (c) wastewater.

should generate its data based on signals from as many real relevant sensors as possible.

In this study, the synchronous fluorescence spectra, the UV light absorbance at $254 \mathrm{~nm}$, and DOC of water samples were analyzed to predict their $\mathrm{BOD}_{5}$ values. Since the fluorescence spectra vary depending on the characteristics of DOMs that are site specific in this study, therefore, all the fluorescence spectra of a sample were utilized.

The specific purposes of this study are as follows: (1) the analysis of synchronous fluorescence spectra of river waters and wastewaters, (2) correlation analyses between water $\mathrm{BOD}_{5}$ and organic parameters (i.e., DOC) and between water $\mathrm{BOD}_{5}$ and optical parameters (i.e., UV light absorbance at $254 \mathrm{~nm}$, synchronous fluorescence spectra (at $270 \sim 300 \mathrm{~nm}$, $310 \sim 370 \mathrm{~nm}, 370 \sim 400 \mathrm{~nm}$, and 400 530 nm)), and (3) development of multiple regression models for the $\mathrm{BOD}_{5}$ prediction using DOC, UV absorbance at $254 \mathrm{~nm}$, and synchronous fluorescence spectra.

\section{Experimental}

2.1. Sampling Locations and Sample Pretreatment. A total of 23 river samples were collected from the Gyeong-An River which flows through the City of Yong In, Korea, at 1-h intervals. In addition, a total of wastewater samples were collected from the Hwa-Do WWTP in the City of Namyangju, Korea, at 1-h intervals. The river samples contained low concentrations of $\mathrm{BOD}_{5}$, while the wastewater samples contained a wider range of $\mathrm{BOD}_{5}$. Once the samples were collected, they were stored under refrigerated condition $\left(4^{\circ} \mathrm{C}\right)$ and transported to the laboratory, in which they were analyzed immediately. Using prewashed GF/F filters (Whatman, USA; nominal pore size: $0.7 \mu \mathrm{m}$ ), SS was removed from 


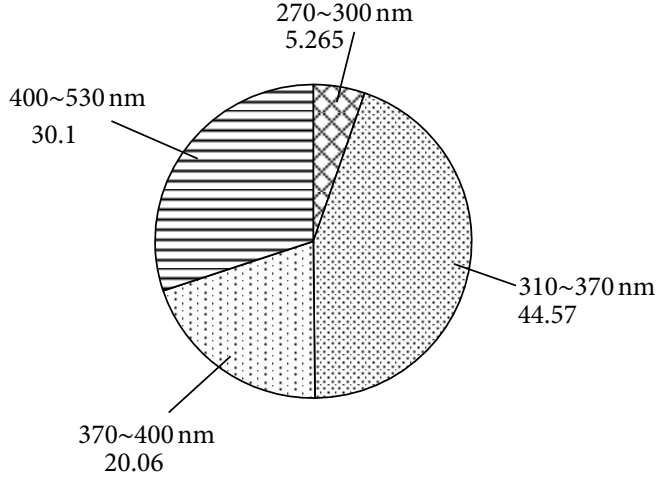

(a)

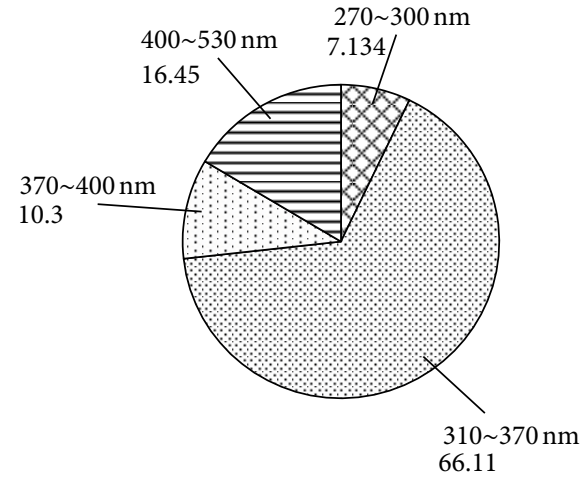

(b)

FIGURE 2: Pie chart of synchronous fluorescence spectra for (a) river water and (b) WWTP effluent.

the samples. SS in water samples often interferes accurate measurements of water quality by scattering light, when the UV spectrophotometry or the synchronous fluorescence measurement is applied to the water samples.

2.2. Analytical Methods. The dissolved organic matters in the filtered samples were measured with an UV spectrophotometer (Shimadzu UV-1800) at $254 \mathrm{~nm}$. The $\mathrm{BOD}_{5}$ of each sample was determined by calculating the decreased amount of the DO over $5 \mathrm{~d}$ (APHA, 2010). The DOC of the samples was calculated by subtracting dissolved inorganic carbon (DIC) from dissolved carbon (DC). The DIC and DC were measured using a TOC analyzer (Shimadzu TOC$\mathrm{V}-\mathrm{CPH}$, Japan). DC concentration of a water sample was determined by combusting a water sample at $680^{\circ} \mathrm{C}$ in the presence of a platinized alumina catalyst and by measuring the resulting $\mathrm{CO}_{2}$ production. On the other hand, the DIC of a water sample was determined through the phosphoric acid digestion of the water followed by the determination of the $\mathrm{CO}_{2}$ production.

The fluorescence spectra of a water sample were measured using a fluorescence spectrometer (Scinco FS-2, Korea). For each sample, synchronous fluorescence spectra for excitation wavelengths ranging from 200 to $600 \mathrm{~nm}$ were recorded using a constant offset (i.e., $\Delta \lambda=30 \mathrm{~nm}$ ). The excitation and emission slits were adjusted to $5 \mathrm{~nm}$ and $5 \mathrm{~nm}$, respectively. Blank spectrum made by deionized water was subtracted from those of each sample to remove the Raman scattering. The UV-visible spectrum of samples was measured using a UV spectrophotometer (Shimadzu UV-1800). The operating conditions of the spectrophotometer are as follows: a resolution of $2 \mathrm{~nm}$, a response of $0.5 \mathrm{~s}$ and a scan speed of $60 \mathrm{~nm} \mathrm{~min}^{-1}$.

2.3. Development of Multiple Regression Models. The correlation coefficients between the $\mathrm{BOD}_{5}$ of water samples and the UV light absorbance at $254 \mathrm{~nm}$ and between the $\mathrm{BOD}_{5}$ and fluorescence spectra were analyzed using the correlation function of Microsoft Excel (Microsoft, USA). The multiple regression with the parameters (i.e., DOC, UV absorbance, and fluorescence spectra) for the development of a model to predict the water $\mathrm{BOD}_{5}$ were carried out using the Data Analysis function of Microsoft Excel.

\section{Results and Discussion}

3.1. Measurement of Synchronous Fluorescence Spectra. In this study, all the spectra obtained at the wavelengths of $270 \mathrm{~nm} \sim 300 \mathrm{~nm}, 310 \mathrm{~nm} \sim 370 \mathrm{~nm}, 370 \mathrm{~nm} \sim 400 \mathrm{~nm}$, and more than $460 \mathrm{~nm}$ for monoaromatic compounds and tryptophan, diaromatic compounds, fulvic acid, humic acids, and other compounds, respectively, were selected as fluorescence parameters after the synchronous fluorescence spectra of 200 600 $\mathrm{nm}$ had been examined. Ferrari and Mingazzini [12] also used these spectra to analyze the compounds in natural DOMs in their study.

Figure 1 shows the average of the values measured by synchronous fluorescence spectra for a blank, 23 stream waters, and 20 wastewaters. Examining the average spectrum of sample excitation wavelength values by samples, the river waters showed peaks at the wavelengths of $310 \mathrm{~nm}$ and $380 \mathrm{~nm}$ while the wastewaters showed peaks at $320 \mathrm{~nm}$ and $400 \mathrm{~nm}$. A peak at the wavelength of 310 320 nm appeared common for all the water samples including the blank. However, the peak occurring at the wavelength between $350 \sim 530 \mathrm{~nm}$ appeared common only for river waters and wastewaters.

The fluorescence intensity ratio of river waters to wastewaters is 1 to 5.6. With synchronous fluorescence spectra $(\Delta \lambda=$ $25 \mathrm{~nm}$ ), a number of compounds present in natural DOM can be identified [12]. Fluorescence spectra of $310 \mathrm{~nm} \sim 320 \mathrm{~nm}$ include naphthol and indoxyl quinoline compounds and $350 \mathrm{~nm} \sim 500 \mathrm{~nm}$ includes 1-amino-2-naphthol-4-sulfonic acid, fulvic acid, flavin adenine dinucleotide, riboflavin, and humic acid.

To estimate compounds in the DOM of samples, the whole spectrum area obtained for each sample type was divided into four subareas for the excitation wavelengths of $270-300 \mathrm{~nm}, 310-370 \mathrm{~nm}, 370-400 \mathrm{~nm}$, and more than $460 \mathrm{~nm}$ (Figure 2). The components of the DOMs in river 

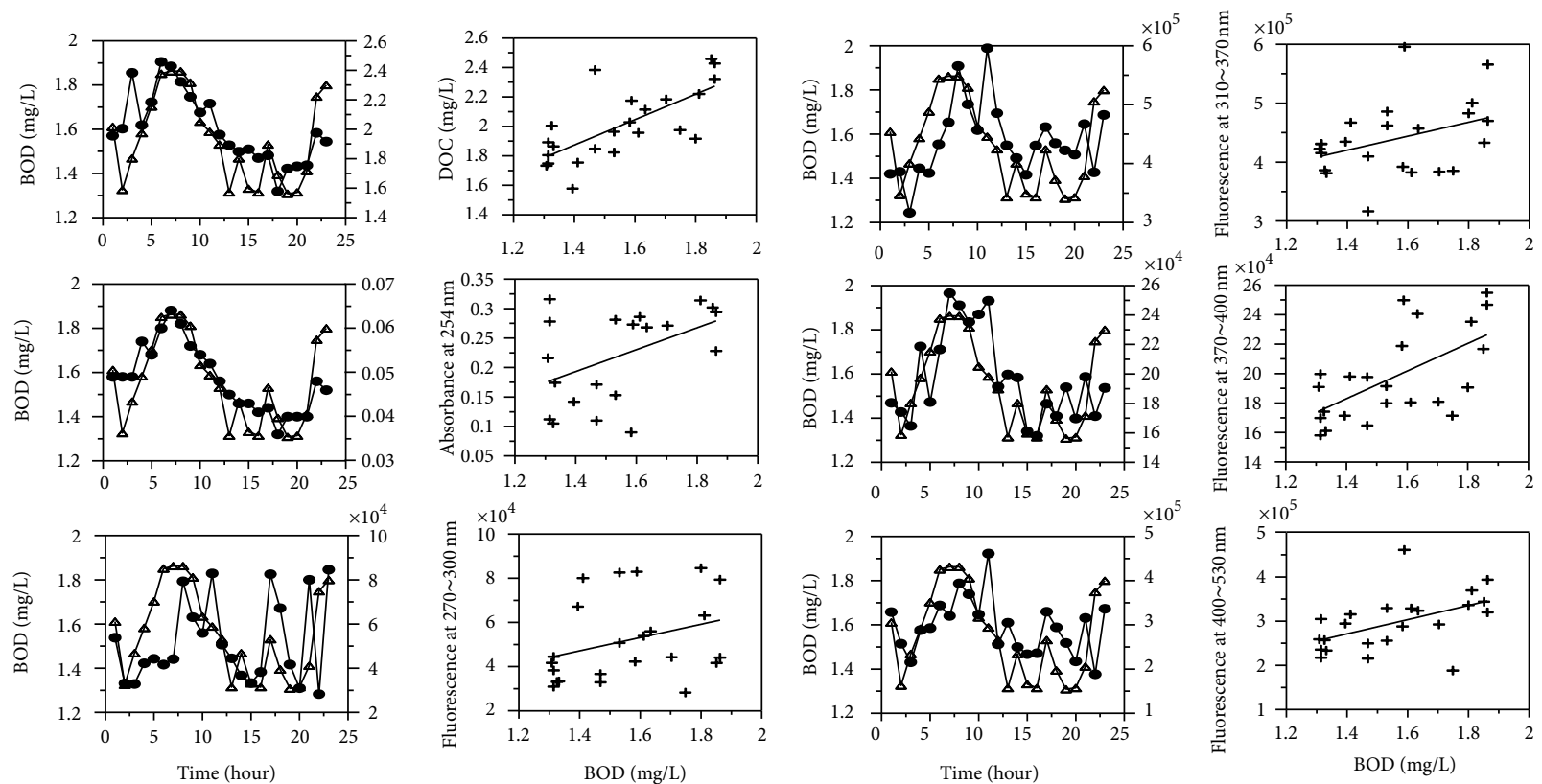

(a) River waters
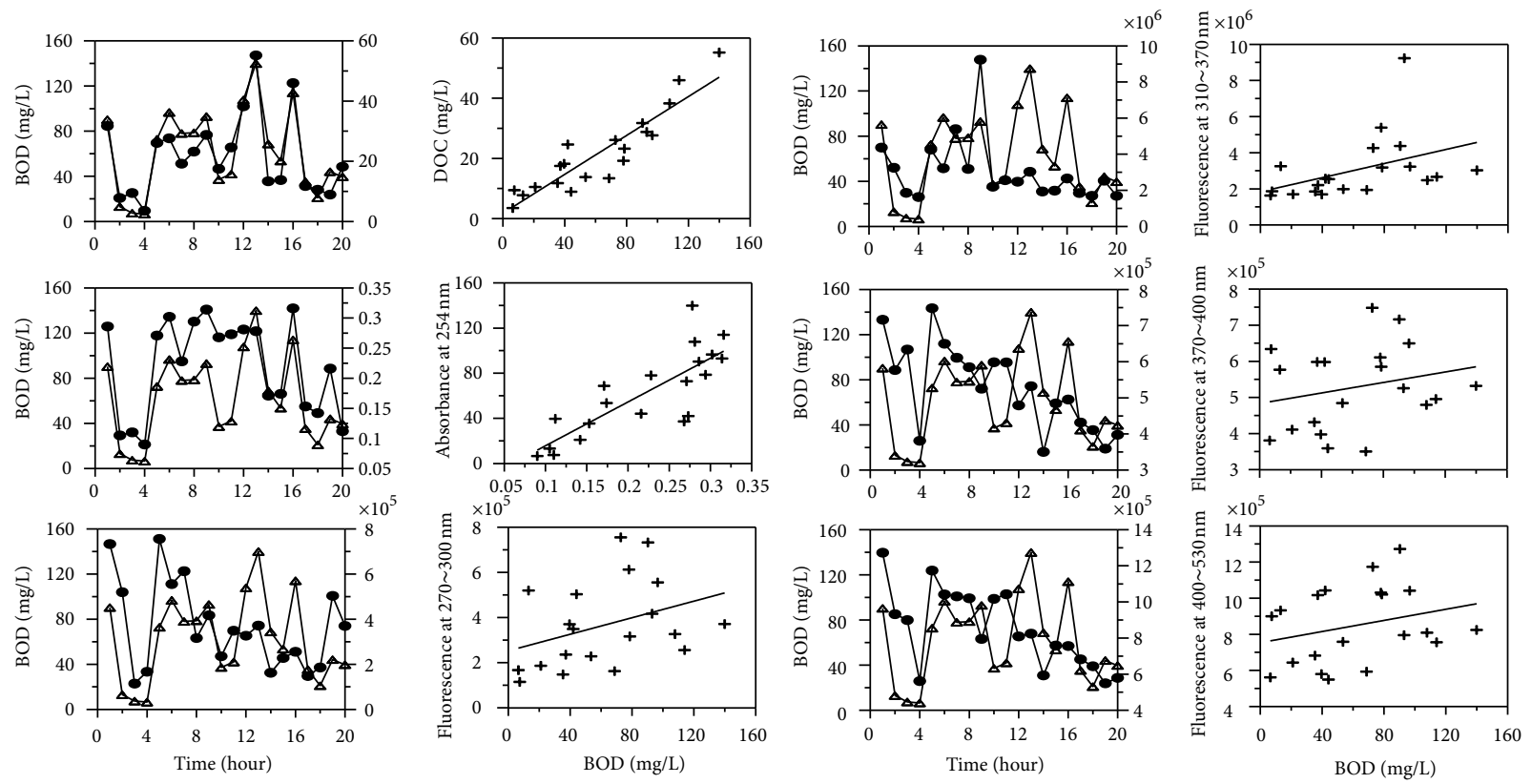

(b) Wastewaters

FIGURE 3: Time profile of $\mathrm{BOD}_{5}$ and correlation between measured $\mathrm{BOD}_{5}$ and other parameters for (a) river waters and (b) wastewaters.

waters were estimated in the following order: diaromatic compounds (44.6\%), humic acids (30.1\%), fulvic acids (20.6\%), and monoaromatic compounds and tryptophan (5.3\%). Those in wastewaters were estimated in the following order: diaromatic compounds (66.1\%), humic acids and other compounds (16.5\%), fulvic acids (10.3\%), and monoaromatic compounds and tryptophan (7.1\%).

3.2. Correlation between $\mathrm{BOD}_{5}$ and Fluorescence Parameters. In order to rapidly estimate $\mathrm{BOD}_{5}$ of a water, the UV spectra [14], the optical scattering (i.e., fluorescence) [18], the UV light absorption at $280 \mathrm{~nm}$ [16], COD [15], and so forth, were utilized. These parameters are divided into organic material parameters (e.g., COD, etc.) and optical parameters (e.g., UV light absorbance, fluorescence spectra, etc.). In fact, none of the parameters has been able to successfully predict the $\mathrm{BOD}_{5}$ of water samples perfectly.

Thomas et al. [14] suggested that organic matter be classified into $\mathrm{BOD}_{5}, \mathrm{COD}, \mathrm{TOC}$, and substances absorbing UV light. The $\mathrm{BOD}_{5}$ is related to oxidizable minerals, carbohydrates, and biodegradable organic matters. The COD is related to oxidizable minerals, carbohydrates, 


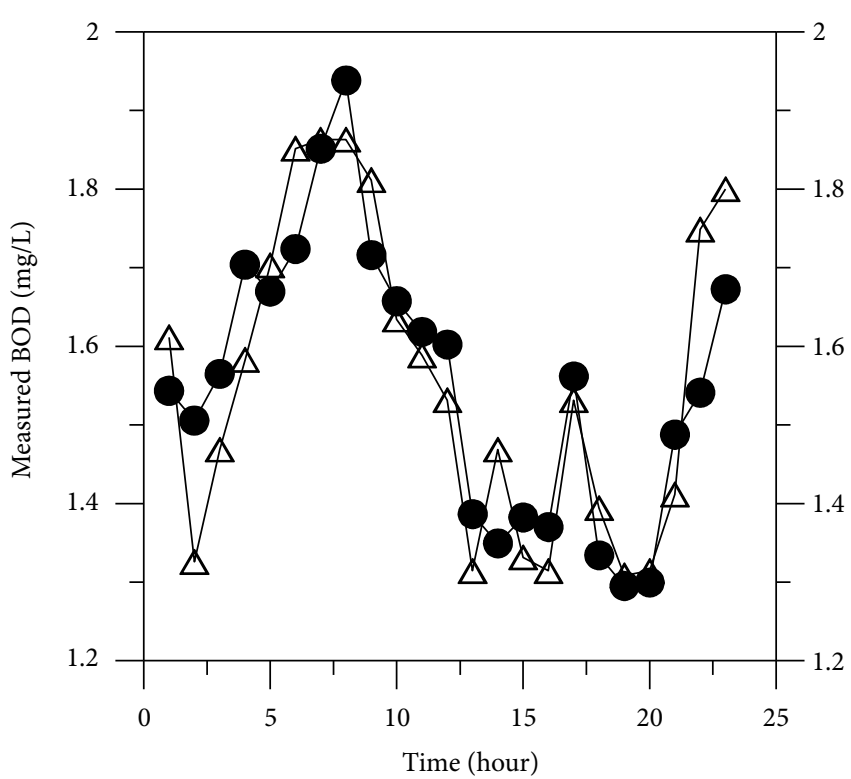

(a)

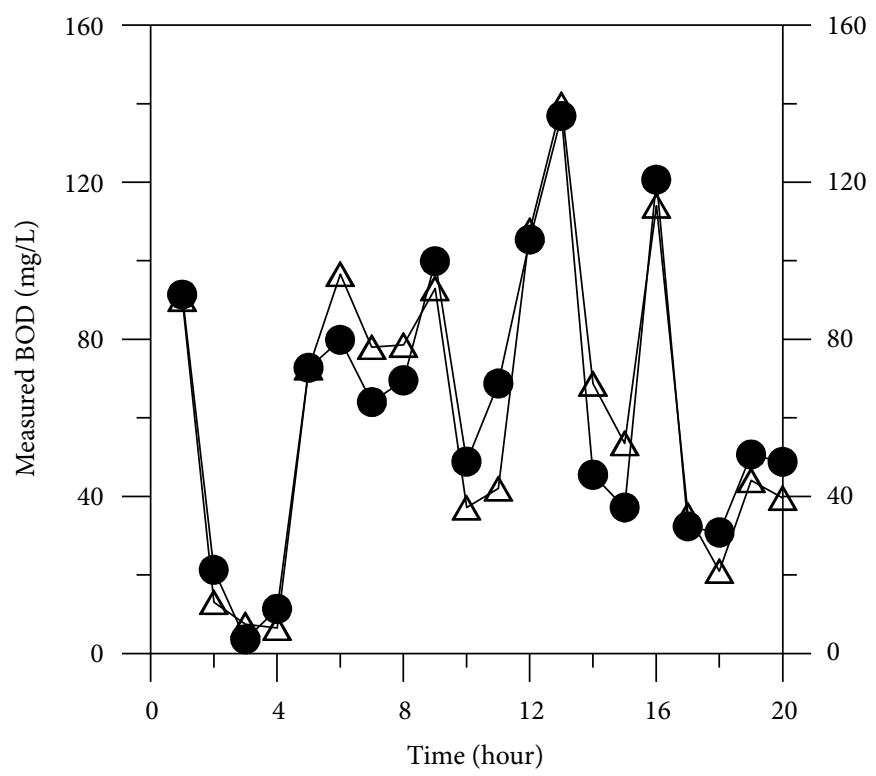

(c)

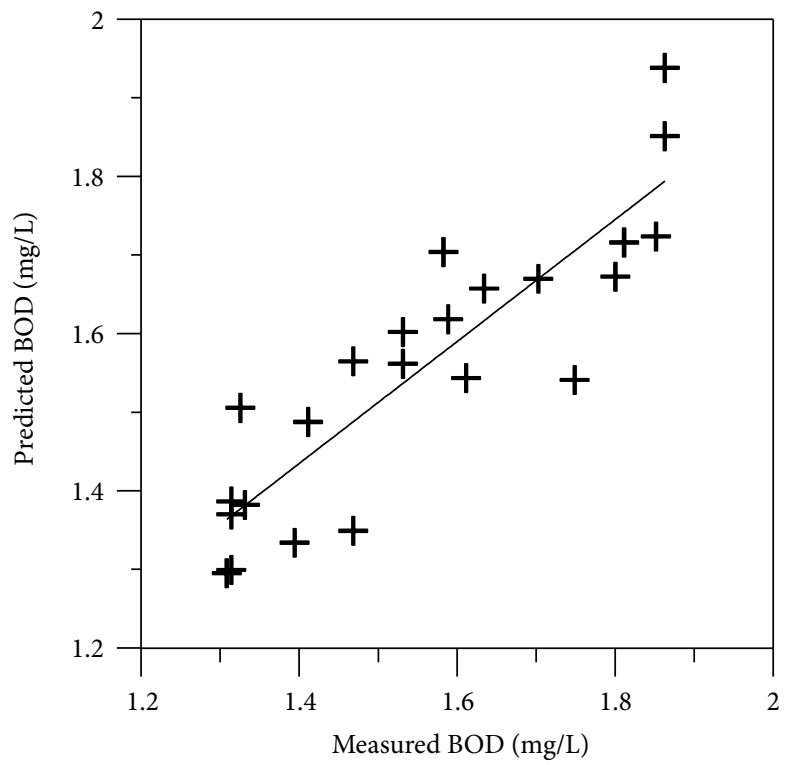

(b)

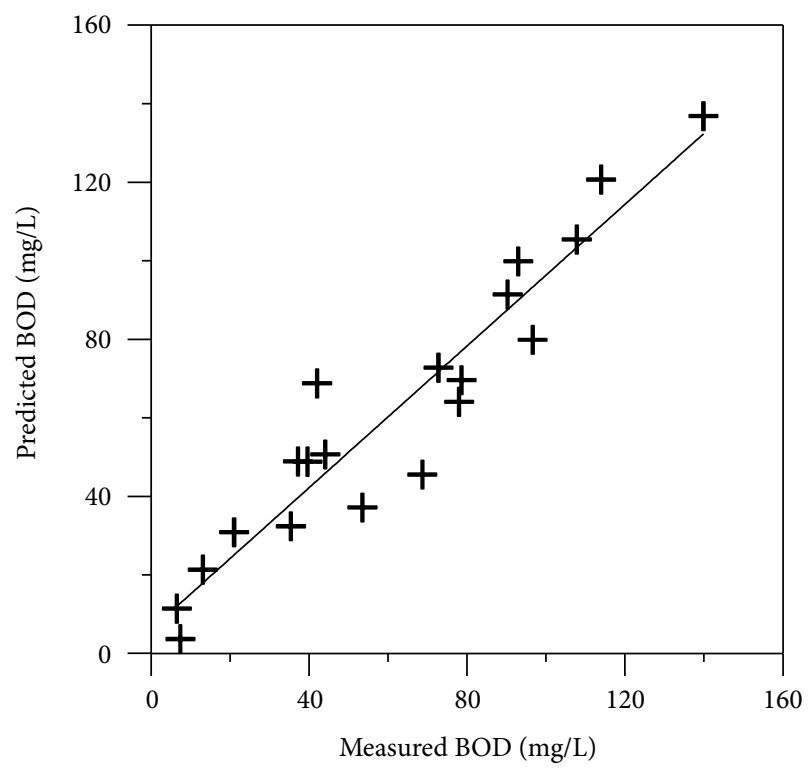

(d)

FIGURE 4: Correlation between manually measured $\mathrm{BOD}_{5}$ and model predictions for (a) river waters and (b) wastewaters.

biodegradable organic matters, and humic substances. The TOC is related to carbohydrates, biodegradable organic matters, humic substances, aromatic hydrocarbons, and aliphatic hydrocarbons. Lastly, the UV light absorption is related to biodegradable organic matters, humic substances, aromatic hydrocarbons, and UV light-absorbing minerals. Since each of COD, TOC, and the UV absorption only identifies some of the organic matter related to $\mathrm{BOD}_{5}$, the predicted $\mathrm{BOD}_{5}$ values based on the parameter should be erroneous.

Therefore, this study used both organic parameter and optical parameters to improve the accuracy of the $\mathrm{BOD}_{5}$ estimation: DOC as the organic parameter, UV absorbance at $254 \mathrm{~nm}$, and fluorescence spectra at $270 \sim 300 \mathrm{~nm}$, at $310 \sim$ $370 \mathrm{~nm}$, at $370 \sim 400 \mathrm{~nm}$, and at $400 \sim 530 \mathrm{~nm}$ as the optical parameters (Table 1). The river waters contained 1.3 $1.9 \mathrm{mg} \mathrm{L}^{-1}$ of $\mathrm{BOD}_{5}$ and $1.6 \sim 2.5 \mathrm{mg} \mathrm{L}^{-1}$ of DOC. In addition, $0.036 \sim 0.64$ of the UV absorbance at $254 \mathrm{~nm}$ and $28252 \sim$ 84575 of fluorescence spectrum intensity at $270 \sim 300 \mathrm{~nm}$, $381099 \sim 595808$ at $310 \sim 370 \mathrm{~nm}, 158019 \sim 254822$ at 370 $400 \mathrm{~nm}$, and 188096 461216 at 400 530 nm were observed for the water.

The wastewater samples contained $6.5 \sim 140 \mathrm{mg} \mathrm{L}^{-1}$ of $\mathrm{BOD}_{5}$ and $3.5 \sim 55.2 \mathrm{mg} \mathrm{L}^{-1}$ of DOC. In addition, 0.090 0.310 of the UV absorbance at $254 \mathrm{~nm}$ and 114609 755116 of fluorescence intensity at $270 \sim 300 \mathrm{~nm}, 1629452 \sim 9233331$ at 
TABLE 1: $\mathrm{BOD}_{5}$ and different parameters measured for river waters and wastewaters.

\begin{tabular}{|c|c|c|c|c|c|c|c|}
\hline \multirow{2}{*}{ Sample } & \multirow{2}{*}{$\mathrm{BOD}_{5} \mathrm{mg} \mathrm{L}^{-1}$} & \multirow{2}{*}{$\mathrm{DOC} \mathrm{mg} \mathrm{L}^{-1}$} & \multirow{2}{*}{ Absorbance at $254 \mathrm{~nm}$} & \multicolumn{4}{|c|}{ Fluorescence intensity (AU) } \\
\hline & & & & $270 \sim 300 \mathrm{~nm}$ & $310 \sim 370 \mathrm{~nm}$ & $370 \sim 400 \mathrm{~nm}$ & $400 \sim 530 \mathrm{~nm}$ \\
\hline \multicolumn{8}{|c|}{ River waters } \\
\hline Mean & 1.6 & 2.0 & 0.049 & 53600 & 450202 & 201142 & 300654 \\
\hline S.D. & 0.2 & 0.2 & 0.008 & 19294 & 57116 & 30772 & 64592 \\
\hline Min & 1.3 & 1.6 & 0.036 & 28252 & 381099 & 158019 & 188096 \\
\hline $\operatorname{Max}$ & 1.9 & 2.5 & 0.064 & 84575 & 595808 & 254822 & 461216 \\
\hline \multicolumn{8}{|c|}{ Waste-waters } \\
\hline Mean & 62.0 & 21.8 & 0.219 & 366183 & 3050004 & 528135 & 849118 \\
\hline S.D. & 37.9 & 13.4 & 0.079 & 192547 & 1771048 & 116813 & 213009 \\
\hline Min & 6.5 & 3.5 & 0.090 & 114609 & 1629452 & 350192 & 549098 \\
\hline Max & 139.9 & 55.2 & 0.310 & 755116 & 9233331 & 748122 & 1272352 \\
\hline
\end{tabular}

TABLE 2: Correlation coefficients between parameters for (a) river waters and (b) wastewaters.

(a) River waters

\begin{tabular}{|c|c|c|c|c|c|c|c|}
\hline Parameter & $\begin{array}{c}\mathrm{BOD}_{5} \\
\left(\mathrm{mg} \mathrm{L}^{-1}\right)\end{array}$ & $\begin{array}{c}\mathrm{DOC} \\
\left(\mathrm{mg} \mathrm{L}^{-1}\right)\end{array}$ & $\begin{array}{c}\text { Absorbance } \\
\text { at } 254 \mathrm{~nm}\end{array}$ & $\begin{array}{c}\text { Fluorescence } \\
\text { at } 270 \sim 300 \mathrm{~nm}\end{array}$ & $\begin{array}{c}\text { Fluorescence } \\
\text { at } 310 \sim 370 \mathrm{~nm}\end{array}$ & $\begin{array}{c}\text { Fluorescence } \\
\text { at } 370 \sim 400 \mathrm{~nm}\end{array}$ & $\begin{array}{l}\text { Fluorescence } \\
\text { at } 400 \sim 530 \mathrm{~nm}\end{array}$ \\
\hline $\mathrm{BOD}_{5}\left(\mathrm{mg} \mathrm{L}^{-1}\right)$ & 1 & & & & & & \\
\hline $\mathrm{DOC}\left(\mathrm{mg} \mathrm{L}^{-1}\right)$ & 0.72 & 1 & & & & & \\
\hline $\begin{array}{l}\text { Absorbance } \\
\text { at } 254 \mathrm{~nm}\end{array}$ & 0.80 & 0.91 & 1 & & & & \\
\hline $\begin{array}{l}\text { Fluorescence at } \\
270 \sim 300 \mathrm{~nm}\end{array}$ & 0.32 & -0.05 & 0.02 & 1 & & & \\
\hline $\begin{array}{l}\text { Fluorescence at } \\
310 \sim 370 \mathrm{~nm}\end{array}$ & 0.38 & 0.15 & 0.26 & 0.75 & 1 & & \\
\hline $\begin{array}{l}\text { Fluorescence at } \\
370 \sim 400 \mathrm{~nm}\end{array}$ & 0.62 & 0.58 & 0.73 & 0.41 & 0.70 & 1 & \\
\hline $\begin{array}{l}\text { Fluorescence at } \\
400 \sim 530 \mathrm{~nm}\end{array}$ & 0.50 & 0.37 & 0.46 & 0.78 & 0.80 & 0.75 & 1 \\
\hline
\end{tabular}

(b) Wastewaters

\begin{tabular}{|c|c|c|c|c|c|c|c|}
\hline Parameter & $\begin{array}{c}\mathrm{BOD}_{5} \\
\left(\mathrm{mg} \mathrm{L}^{-1}\right)\end{array}$ & $\begin{array}{c}\text { DOC } \\
\left(\mathrm{mg} \mathrm{L}^{-1}\right)\end{array}$ & $\begin{array}{c}\text { Absorbance } \\
\text { at } 254 \mathrm{~nm}\end{array}$ & $\begin{array}{c}\text { Fluorescence } \\
\text { at } 270 \sim 300 \mathrm{~nm}\end{array}$ & $\begin{array}{c}\text { Fluorescence } \\
\text { at } 310 \sim 370 \mathrm{~nm}\end{array}$ & $\begin{array}{c}\text { Fluorescence } \\
\text { at } 370 \sim 400 \mathrm{~nm}\end{array}$ & $\begin{array}{c}\text { Fluorescence } \\
\text { at } 400 \sim 530 \mathrm{~nm}\end{array}$ \\
\hline $\mathrm{BOD}_{5}\left(\mathrm{mg} \mathrm{L}^{-1}\right)$ & 1 & & & & & & \\
\hline $\mathrm{DOC}\left(\mathrm{mg} \mathrm{L}^{-1}\right)$ & 0.91 & 1 & & & & & \\
\hline $\begin{array}{l}\text { Absorbance } \\
\text { at } 254 \mathrm{~nm}\end{array}$ & 0.81 & 0.76 & 1 & & & & \\
\hline $\begin{array}{l}\text { Fluorescence at } \\
270 \sim 300 \mathrm{~nm}\end{array}$ & 0.36 & 0.27 & 0.42 & 1 & & & \\
\hline $\begin{array}{l}\text { Fluorescence at } \\
310 \sim 370 \mathrm{~nm}\end{array}$ & 0.42 & 0.30 & 0.51 & 0.54 & 1 & & \\
\hline $\begin{array}{l}\text { Fluorescence at } \\
370 \sim 400 \mathrm{~nm}\end{array}$ & 0.24 & 0.31 & 0.47 & 0.61 & 0.39 & 1 & \\
\hline $\begin{array}{l}\text { Fluorescence at } \\
400 \sim 530 \mathrm{~nm}\end{array}$ & 0.27 & 0.32 & 0.54 & 0.63 & 0.37 & 0.97 & 1 \\
\hline
\end{tabular}

$310 \sim 370 \mathrm{~nm}, 350192 \sim 748122$ at 370 400 nm, and 549098 1272352 at $400 \sim 530 \mathrm{~nm}$ were observed (Table 1).

In Figure 3, $\mathrm{BOD}_{5}$ and other parameters were drawn for (a) river waters and (b) wastewaters to analyze the correlation between the measured $\mathrm{BOD}_{5}$ and each parameter. Moreover, the time profile of $\mathrm{BOD}_{5}$ was provided to illustrate its hourly variation.
The correlation coefficients between $\mathrm{BOD}_{5}$ and the UV absorption or other fluorescence intensity at different wavelengths were obtained for river waters and wastewaters (Table 2 ). For the river waters, the parameter that has a high correlation with the measured $\mathrm{BOD}_{5}$ was in order of the UV absorbance at $254 \mathrm{~nm}(r=0.80)$, DOC $(r=0.72)$, fluorescence intensity at $370 \sim 400 \mathrm{~nm}(r=0.62)$, fluorescence 
TABLE 3: Summary of model development for predicting $\mathrm{BOD}_{5}$ of (a) river waters and (b) wastewaters.

(a) River waters

\begin{tabular}{|c|c|c|c|c|c|}
\hline Number in Model & Variables in model & $R$-square & Adjust $R$-square & $C_{P}$ & MSE \\
\hline 1 & $\mathrm{UV}_{254}$ & 0.6322 & 0.6147 & 11.10 & 0.9839 \\
\hline 2 & DOC & 0.5117 & 0.4885 & 7.86 & 1.3062 \\
\hline 3 & $\mathrm{~F} 1, \mathrm{~F} 2, \mathrm{~F} 3$, and $\mathrm{F} 4$ & 0.4163 & 0.2866 & 0.71 & 0.3904 \\
\hline 4 & DOC, $\mathrm{UV}_{254}$ & 0.6326 & 0.5959 & 9.11 & 0.4914 \\
\hline 5 & $\mathrm{DOC}, \mathrm{F} 1, \mathrm{~F} 2, \mathrm{~F} 3$, and F4 & 0.6636 & 0.5646 & -3.95 & 0.1500 \\
\hline 6 & $\mathrm{UV}_{254}, \mathrm{~F} 1, \mathrm{~F} 2, \mathrm{~F} 3$, and F4 & 0.7770 & 0.7114 & 7.00 & 0.1193 \\
\hline 7 & $\mathrm{DOC}, \mathrm{UV}_{254}, \mathrm{~F} 1, \mathrm{~F} 2, \mathrm{~F} 3$, and F4 & 0.7770 & 0.6934 & 7.00 & 0.0994 \\
\hline
\end{tabular}

(b) Wastewaters

\begin{tabular}{|c|c|c|c|c|c|}
\hline Number in model & Variables in model & $R$-square & Adjust $R$-square & $C_{P}$ & MSE \\
\hline 1 & $\mathrm{UV}_{254}$ & 0.6538 & 0.6345 & 3.29 & 9441.1632 \\
\hline 2 & DOC & 0.8310 & 0.8217 & 7.61 & 4607.0759 \\
\hline 3 & $\mathrm{~F} 1, \mathrm{~F} 2, \mathrm{~F} 3$, and $\mathrm{F} 4$ & 0.2271 & 0.0210 & 35.52 & 5268.8259 \\
\hline 4 & DOC, $\mathrm{UV}_{254}$ & 0.8609 & 0.8445 & 7.45 & 1896.5335 \\
\hline 5 & DOC, F1, F2, F3, and F4 & 0.8901 & 0.8509 & -3.24 & 599.2478 \\
\hline 6 & $\mathrm{UV}_{254}, \mathrm{~F} 1, \mathrm{~F} 2, \mathrm{~F} 3$, and F4 & 0.7140 & 0.6118 & 7.59 & 1559.9272 \\
\hline 7 & $\mathrm{DOC}, \mathrm{UV}_{254}, \mathrm{~F} 1, \mathrm{~F} 2, \mathrm{~F} 3$, and F4 & 0.9024 & 0.8574 & 7.00 & 443.5252 \\
\hline
\end{tabular}

TABLE 4: Multiple linear regression models for predicting BODs of river waters and wastewaters.

\begin{tabular}{|c|c|}
\hline Sample & Multiple regression model \\
\hline River waters & $\begin{aligned} \mathrm{BOD}_{5}\left(\mathrm{mg} \mathrm{L}^{-1}\right)= & 49.93536 \cdot \mathrm{UV}_{254}{ }^{\mathrm{a}}+1.23 \cdot 10^{-5} \cdot \mathrm{FI}_{270 \sim 300 \mathrm{~nm}}+3.32 \cdot 10^{-7} \cdot \mathrm{FI}_{310 \sim 370 \mathrm{~nm}}-2 \cdot 10^{-06} \cdot \mathrm{FI}_{370 \sim 400 \mathrm{~nm}} \\
& -2.4 \cdot 10^{-06} \cdot \mathrm{FI}_{400 \sim 530 \mathrm{~nm}}+0.612293\end{aligned}$ \\
\hline Wastewaters & $\begin{aligned} \text { BOD }_{5}\left(\mathrm{mg} \mathrm{L}^{-1}\right)= & 2.066723 \cdot \mathrm{DOC}+113.2703 \cdot \mathrm{UV}_{254}{ }^{\mathrm{a}}+2.93 \cdot 10^{-5} \cdot \mathrm{FI}_{270 \sim 300 \mathrm{~nm}}+1.96 \cdot 10^{-6} \cdot \mathrm{FI}_{310 \sim 370 \mathrm{~nm}} \\
& -0.00011 \cdot \mathrm{FI}_{370 \sim 400 \mathrm{~nm}}+2.14 \cdot 10^{-5} \cdot \mathrm{FI}_{400 \sim 530 \mathrm{~nm}}+16.6394\end{aligned}$ \\
\hline
\end{tabular}

intensity at $400 \sim 530 \mathrm{~nm}(r=0.50)$, fluorescence intensity at $310 \sim 370 \mathrm{~nm}(r=0.38)$, fluorescence intensity at $270 \sim$ $300 \mathrm{~nm}(r=0.32)$. In case of wastewaters, the measured $\mathrm{BOD}_{5}$ had a higher correlation with $\mathrm{DOC}(r=0.91)$ and the $\mathrm{UV}$ absorbance at $254 \mathrm{~nm}(r=0.81)$.

3.3. Multiple Linear Regression Analysis. Multivariate relationships require a multiple regression analysis involving several explanatory variables for predictors of theoretical interest and control variables [18]. Often multivariate regression is applied to predict a variable (i.e., predictor or dependent variable), which is not easily measurable, with other variables (i.e., independent variables), which are easy to measure. For examples, $\mathrm{COD}, \mathrm{NH}_{4}{ }^{-}$, and $\mathrm{NO}_{3}{ }^{-}$concentrations of water samples were predicted by using $\mathrm{pH}$, temp, conductivity, redox potential DO, and turbidity of the same water [19]. Helling et al. [20] predicted the COD/TOC ratio using $\mathrm{CO}_{2}$ and $\mathrm{O}_{2}$. Lee and Ahn [21] utilized protein-like fluorescence intensities at $220 / 350 \mathrm{~nm}$ and $633 \mathrm{~nm}$ to predict wastewater COD.

If many independent variables are used to explain a dependent variable, the most appropriate regression model should be selected based on the coefficient of determination such as $R_{P}^{2}$ (coefficient of determination of a multiple regression model), $R_{\text {adj }}^{2}$ (adjusted coefficient of determination),
MSE (residual mean of squares), and $C_{P}$ of Mallows among many models which could be set up by correlating available independent variables to the dependent variable of interest.

A regression model is selected if it increases $R_{P}^{2}$ slows, if it makes the $R_{\text {adj }}^{2}$ the maximum and MSE the minimum, and if it makes the $C_{P}$ of Mallows close to $P+1$ value [18].

To select an appropriate regression model for the $\mathrm{BOD}_{5}$ prediction, a total of seven models were developed for river waters and wastewaters and presented in Table 3. From Table 3 (a), the Model 6 was found to be the most appropriate in predicting the $\mathrm{BOD}_{5}$ of river waters since it slowly increased $R_{P}^{2}$ and made $R_{\text {adj }}^{2}$ the maximum. In fact, the Model 7 appeared equivalently appropriate since the MSE of the model was the minimum and it made $C_{P}$ of Mallows closest to $P+1$. However, Model 6 was finally selected for predicting the $\mathrm{BOD}_{5}$ of river waters since it involves fewer variables. By the same token, a total of seven linear regression models were developed to predict the $\mathrm{BOD}_{5}$ of wastewaters, and Model 7 was selected as the most appropriate model after reviewing the result of analyzing each linear regression models (Table 3(b)).

In Table 4, the Model 6 in Table 3(a), a linear regression for predicting the $\mathrm{BOD}_{5}$ of river waters was provided. The input variables for the model are the UV absorbance at $254 \mathrm{~nm}$ and fluorescence intensities at $270 \sim 300 \mathrm{~nm}$, at 310 
$370 \mathrm{~nm}$, at $370 \sim 400 \mathrm{~nm}$, and at $400 \sim 530 \mathrm{~nm}$. The linear regression model for wastewaters (i.e., Model 7 in Table 3(b)) was also provided in Table 4. Its input variables are DOC, the UV absorbance at $254 \mathrm{~nm}$, and fluorescence intensities at $270 \sim 300 \mathrm{~nm}$, at $310 \sim 370 \mathrm{~nm}$, at $370 \sim 400 \mathrm{~nm}$, and at 400 $530 \mathrm{~nm}$.

3.4. Validation of Developed Linear Regression Models for Predicting $\mathrm{BOD}_{5}$. The developed multiple regression models for river waters and wastewaters were, respectively, applied to predict the $\mathrm{BOD}_{5}$ of different sets of river water and wastewater samples. The model predictions were then compared with manual measurements (Figure 4). As shown in the figure, the developed multiple regression models could reasonably well predict the $\mathrm{BOD}_{5}$ of the target water samples. The coefficient for the correlation between manually measured $\mathrm{BOD}_{5}$ and model prediction was calculated 0.78 for river waters, while that for wastewaters was 0.90 . The relative lower correlation coefficient for river waters was attributed to the fact that the concentration was within the range from $1.3 \mathrm{mg} \mathrm{L}^{-1}$ to $1.9 \mathrm{mg} \mathrm{L}^{-1}$; the $\mathrm{BOD}_{5}$ range for the wastewater samples was $6.5 \mathrm{mg} \mathrm{L}^{-1} \sim 139.9 \mathrm{mg} \mathrm{L}^{-1}$.

\section{Conclusion}

In this study, two multiple regression models were developed to predict the $\mathrm{BOD}_{5}$ of two types of environmental waters: one for river waters and the other for wastewaters. The model for river waters predicts $\mathrm{BOD}_{5}$ using the data of the UV absorbance at $254 \mathrm{~nm}$ and fluorescence intensities at 270 $300 \mathrm{~nm}$, at $310 \sim 370 \mathrm{~nm}$, at $370 \sim 400 \mathrm{~nm}$, and at $400 \sim 530 \mathrm{~nm}$. The model for wastewaters was utilizing the data of DOC, the UV absorbance at $254 \mathrm{~nm}$, and fluorescence intensities at $270 \sim 300 \mathrm{~nm}$, at $310 \sim 370 \mathrm{~nm}$, at $370 \sim 400 \mathrm{~nm}$, and at 400 $530 \mathrm{~nm}$. The developed models reasonably well predicted the $\mathrm{BOD}_{5}$ of the river waters and the wastewater samples; correlation coefficients between the model-predicted and manually measured BODs were 0.78 for the river waters and 0.90 for wastewaters.

In fact, the data used for predicting the $\mathrm{BOD}_{5}$ of two types of water samples can be measured using an on-line optical sensors. Therefore, if the $\mathrm{BOD}_{5}$ is estimated using the approach proposed in this study, its measurement can be done rapidly. In addition, this approach can be applied to develop a software sensor for the $\mathrm{BOD}_{5}$ measurement which can be implemented in an on-line water quality monitoring system for streams or WWTP discharges.

\section{Acknowledgment}

This work was supported by the R\&D program of MKE/KEIT (R\&D Program no.: 10037331, Development of Core Water Treatment Technologies based on Intelligent BT-NT-IT Fusion Platform).

\section{References}

[1] American Public Health Association, American Water Works Association, and Water Environment Federation, Standard Methods For the Examination of Water and Wastewater, vol. 21, American Public Health Association, 2005.

[2] J. Hur and D. S. Kong, "Use of synchronous fluorescence spectra to estimate biochemical oxygen demand (BOD) of urban rivers affected by treated sewage," Environmental Technology, vol. 29, no. 4, pp. 435-444, 2008.

[3] W. Bourgeois, J. E. Burgess, and R. M. Stuetz, "On-line monitoring of wastewater quality: a review," Journal of Chemical Technology and Biotechnology, vol. 76, no. 4, pp. 337-348, 2001.

[4] N. Hudson, A. Baker, D. Ward et al., "Can fluorescence spectrometry be used as a surrogate for the Biochemical Oxygen Demand (BOD) test in water quality assessment? An example from South West England," Science of the Total Environment, vol. 391, no. 1, pp. 149-158, 2008.

[5] A. Kumlanghan, P. Kanatharana, P. Asawatreratanakul, B. Mattiasson, and P. Thavarungkul, "Microbial BOD sensor for monitoring treatment of wastewater from a rubber latex industry," Enzyme and Microbial Technology, vol. 42, no. 6, pp. 483-491, 2008.

[6] D. Chen, Y. Cao, B. Liu, and J. Kong, "A BOD biosensor based on a microorganism immobilized on an $\mathrm{Al}_{2} \mathrm{O}_{3}$ sol-gel matrix," Analytical and Bioanalytical Chemistry, vol. 372, no. 5-6, pp. 737-739, 2002.

[7] I. S. Chang, J. K. Jang, G. C. Gil et al., "Continuous determination of biochemical oxygen demand using microbial fuel cell type biosensor," Biosensors and Bioelectronics, vol. 19, no. 6, pp. 607-613, 2004.

[8] R. Iranpour, O. Mogaddam, B. Bina, V. Abkian, and M. Vossoughi, "Comment on: 'response characteristic of a deadcell BOD sensor' by qiaan Z and Tan TC," Water Research, vol. 33, no. 2, pp. 595-598, 1999.

[9] I. C. Grieve, "Determination of dissolved organic matter in stream water using visible spectrophotometry," Earth Surface Processes and Landforms, vol. 10, pp. 75-78, 1985.

[10] M. Nataraja, Y. Qin, and E. A. Seagren, "Ultraviolet spectrophotometry as an index parameter for estimating the biochemical oxygen demand of domestic wastewater," Environmental Technology, vol. 27, no. 7, pp. 789-800, 2006.

[11] N. Matsche and K. Stumwohrer, "UV absorption as controlparameter for biological treatment plants," Water Science Technology, vol. 33, pp. 211-218, 1996.

[12] G. M. Ferrari and M. Mingazzini, "Synchronous fluorescence spectra of dissolved organic matter (DOM) of algal origin in marine coastal waters," Marine Ecology Progress Series, vol. 125, no. 1-3, pp. 305-315, 1995.

[13] A. Baker and R. Inverarity, "Protein-like fluorescence intensity as a possible tool for determining river water quality," Hydrological Processes, vol. 18, no. 15, pp. 2927-2945, 2004.

[14] O. Thomas, F. Theraulaz, C. Agnel, and S. Suryani, "Advanced UV examination of wastewater," Environmental Technology, vol. 17, no. 3, pp. 251-261, 1996.

[15] C. M. A. Ademoroti, "Model to predict BOD from COD values," Effluent \& Water Treatment Journal, vol. 26, no. 3-4, pp. 80-84, 1986.

[16] S. K. E. Brookman, "Estimation of biochemical oxygen demand in slurry and effluents using ultra-violet spectrophotometry," Water Research, vol. 31, no. 2, pp. 372-374, 1997. 
[17] S. Jacobsen and A. L. Jensen, "On-line measurement in wastewater treatment plants: sensor development and assessment of comparability of on-line sensors," in Monitoring of Water Quality, pp. 89-102, 1998.

[18] C. H. Jun, M. G. Jeong, and H. S. Lee, Engineering Applied Statistics, vol. 1, Hongrueng Science Publishers, 2004.

[19] M. Hack and M. Kohne, "Estimation of wastewater process parameters using neural networks," Water Science and Technology, vol. 33, pp. 101-115, 1996.

[20] C. Helling, P. Vanrolleghem, V. Loosdrecht, and J. Heijen, "The potential of off-gas analyses for monitoring wastewater treatment plants," Water Science and Technology, vol. 33, pp. 13-23, 1996.

[21] S. Lee and K. H. Ahn, "Monitoring of COD as an organic indicator in waste water and treated effluent by fluorescence excitation-emission (FEEM) matrix characterization," Water Science and Technology, vol. 50, pp. 57-63, 2004. 

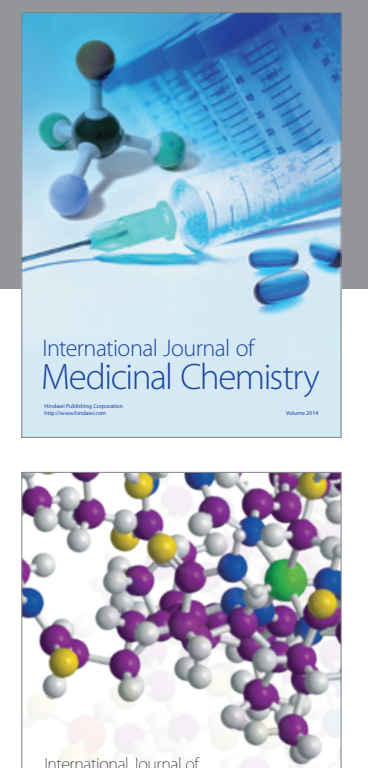

\section{Carbohydrate} Chemistry

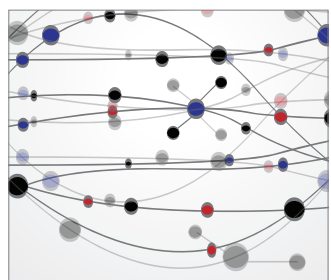

The Scientific World Journal
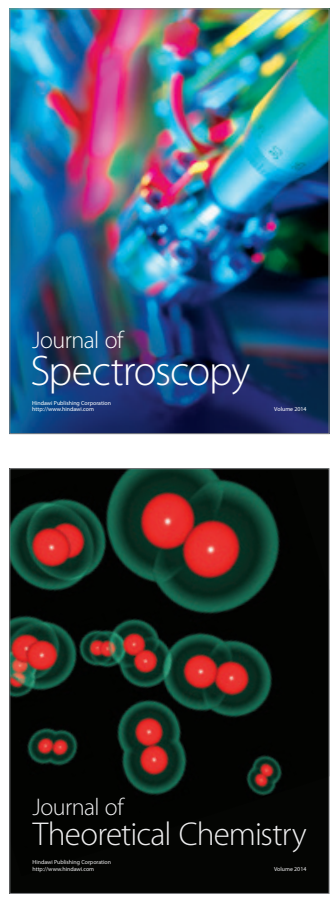
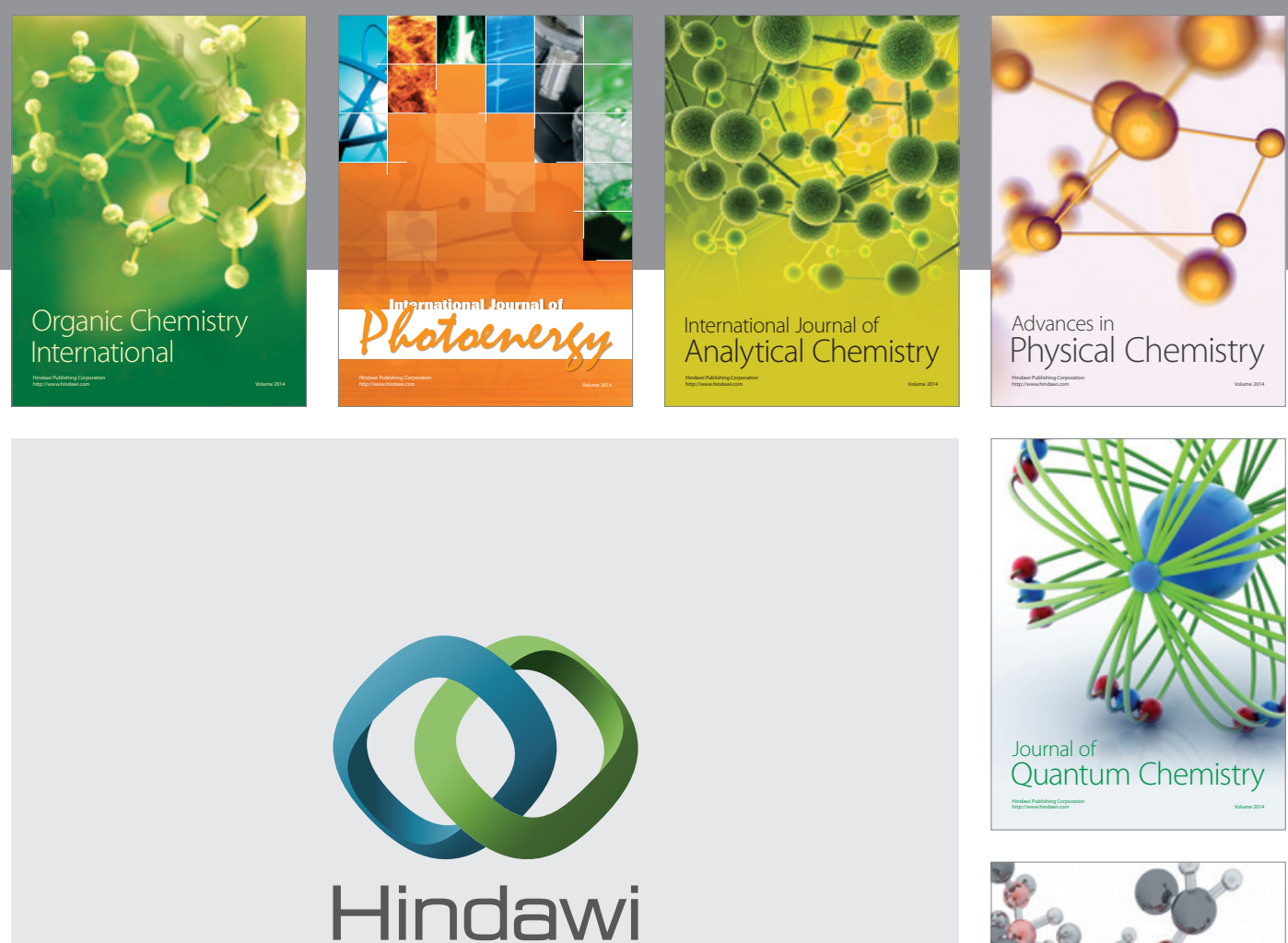

Submit your manuscripts at

http://www.hindawi.com

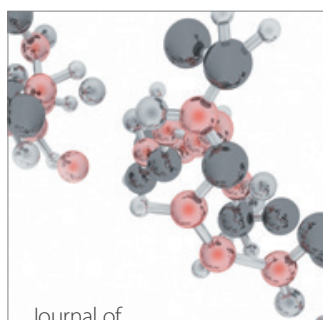

Analytical Methods

in Chemistry

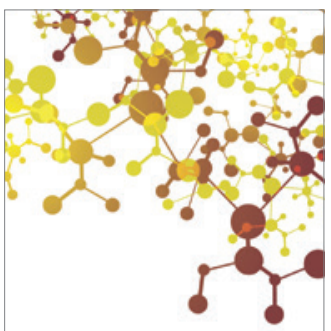

Journal of

Applied Chemistry

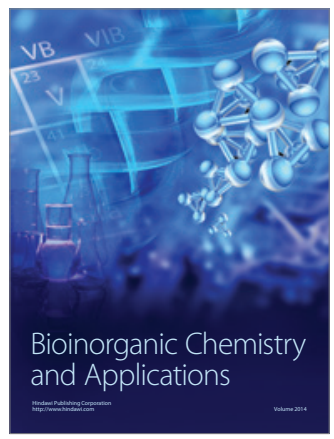

Inorganic Chemistry
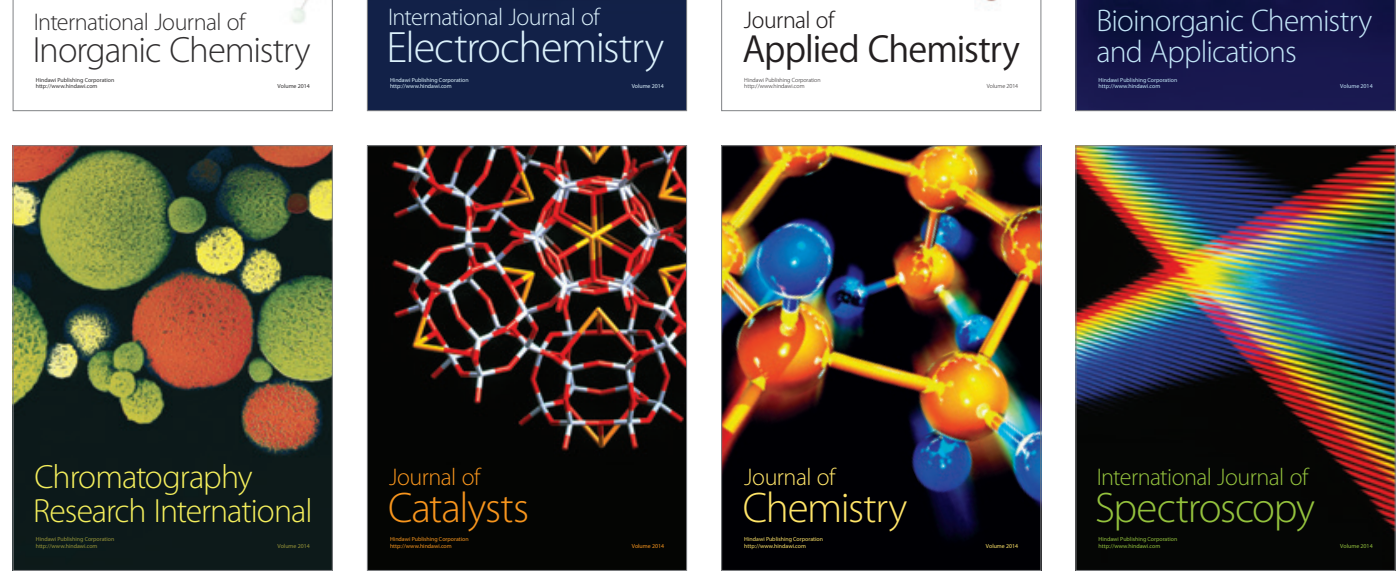